\title{
AKULTURASI ISLAM DENGAN \\ TRADISI PERKAWINAN MASYARAKAT BANGSAWAN SASAK (Studi Di Kecamatan Kopang Kabupaten Lombok Tengah)
}

\author{
M. Najamudin Aminullah \\ STIT Darussalimin NW Praya
}

\begin{abstract}
This study aims to study and describe the elements of Islam that is constructed in the implementation Sasak tradition, the tradition of aristocratic society wedding Kopang Sasak Lombok. Tradition, seen from the perspective of religious anthropology is part of human culture. By using anthropological approach, this study intends to reveal: how the process of marriage in society Sasak ?, How acculturation between Islam and the traditions of the community marital Duke Sasak, a character who acts and patterns of acculturation? The results of research show that the tradition of aristocratic society Sasak have room for Knowledge and value systems and behaviors that are reflected in the behavior of the deacon. His form is displayed through their own behavior, whether in the form of speech, reading, Busty-awenk (rules exist), symbols, especially on wedding traditions. The implementation of Sasak Kopang wedding tradition covers three parts. First: pre wedding or introductory period. Both marriage and marriage in the form of madrid, patience, and ngawinang. And third, in the form of wound post-wedding shoots (pisuke / gantiran), push the hand-over, ngongkolang and aji manners (value prices by social statafikasi). Sasak tradition is the formulation of local resources (local knowledge) in which there are indigenous traditions and elements of Islamic teachings that sifistikhumanistic. The elements constructed in the Sasak tradition are found in the customary values and behavior system of the tradition of marriage. And his family later to bring them into the family life of a harmonious, balanced (KAFA> 'ah) and happy (saki> nah, mawaddah, and mercy)

Keywords: Acculturation, Islam, Sasak Tradition
\end{abstract}

\section{Pendahuluan}

Manusia sebagai makhluk sosial, dalam fitrahnya, saling membutuhkan satu sama lain, di antara kebutuhan manusia yang paling urgen adalah kebutuhan terhadap pasangan hidup, membentuk keluarga yang bahagia dan sejahtera. Untuk mencapai yang dimaksud, dalam tradisi Sasak, khususnya bagi pria harus mempersiapkan diri 
sedini dan sematang mungkin dalam segala segi, ${ }^{1}$ mengingat mereka akan menjadi sosok pemimpin kecil dalam lingkup keluarganya nanti dan hal ini memicu kelompok masyarakat untuk mementukan prilaku yang bisa mencerminkan hal-hal yang mengarah pada persiapan pernikahan yang lambat laun prilaku tersebut menjadi suatu kebiasaan yang tidak bisa tidak, menjadi dogma dalam suatu adat istiadat. Adat terbentuk berawal dari pilaku kelompok masyarakat secara terus-menerus dan menjadi kebiasaan yang bisa mengikat masyarakat yang satu sama lain.

Dalam budaya pernikahan Bangsawan Sasak ${ }^{2}$ Lombok, berkembang adat tradisi mengharuskan anak gadis bangsawannya menikah dengan laki-laki dari garis keturunan bangsawan dan tidak boleh menikah dengan laki-laki dari garis jajar karang. Dalam dogma yang berkembang, kalangan bangsawan adalah kalangan yang memiliki strata sosial yang lebih tinggi dari kalangan jajar karang. Orang bangsawan selalu identik dengan orang yang memiliki pendidikan yang baik, bertutur kata sopan, bertindak tanduk baik dan sopan, tahu bagaimana cara memperlakuakan orang-orang sekelilingnya menurut strata sosial mereka, dan tergolong orang yang kaya. Dalam prakteknya keharusan anak gadis menikah dengan sesama bangsawan sebagai usaha untuk mengangkat strata sosial perempuan itu, dan supaya anaknya kelak menyandang gelar kebangsawanan, mendapat jaminan kehormatan, kedudukan, dan ekonomi, meghindari pemilihan pasangan yang hanya bermodal cinta, serta untuk mendapatkan keamanan dan kesejahteraan.

Upaya pencegahan pernikahan anak gadis dengan laki-laki non Bangsawan selalu diupayakan. Sanksi adat yang biasanya diberlakukan bagi pelanggar ketentuan adat ini cenderung bersifat sikap. Seperti bagi gadis bangsawan yang telah melarikan diri untuk menikah dengan pria di luar strata kebangsawanannya, maka sanksinya akan dibuang dan tidak diakui lagi sebagai bagian dari keluarganya serta pemutusan hak waris-mewaris. Ini adalah sikap yang dilakukan oleh seluruh keluarga bangsawan sebagai bentuk sikap adat yang mereka lakuakan secara kolektif.

${ }^{1}$ Rahmat Hakim, Hukum Perkawinan Islam (Bandung: Pustaka Setia, 2000), 13.

${ }^{2}$ Sasak adalah suku asli pulau Lombok, meskipun di pulau Lombok terdapat beberapa komunitas masyarakat yang berasal dari suku lain, seperti suku Bali yang banyak berdomisi di Lombok bagian barat, sebagian kecil di Lombok Tengah dan sebagian kecil lagi di Lombok Utara, selain suku bali di Lombok juga terdapat Suku Sumbawa yang hidup berpencar di beberapa wilayah di sekitar Lombok Timur. Di bagian pesisir Lombok Timur banyak dijumpai keturunan Bugis dan Makasar (Khoiruddin M.Hum, 2 Maret 2012). 
Dari sudut sebelum Islam, budaya tradisi ini terus-menerus dipertahankan sebagai aturan dan ukuran tingkah laku dan dipandang memiliki nilai luhur yang tinggi, yang mampu menjebatani pemenuhan kebutuhan manusia dan etika tingkah laku. Namun, dari sudut Islam, tentu hal semacam itu tidak sesuai dengan Islam yang membawa ajaran kesejajaran (quality), kesamaan hak, keadilan, dan kesejahteraan, dan saling menghormati.

Persoalannya kemudian adalah bagaimana tradisi tersebut bisa bertahan dan bagaimana tradisi tersebut bisa berinteraksi dengan agama (Islam). Dalam konteks Islam, unsur-unsur dalam budaya tradisi yang tidak sesuai dengan Islam harus dihilangkan. Dalam konteks antropologi, tradisi merupakan bagian dari kebudayaan manusia. Budaya tradsi berisi seperangkat sistem nilai, system tingkah laku, keamanandan kesejahteraan, yang mengandung nilai luhur yang harus dipertahankan dan dilesarikan secara turun temurun, dua aliran yang berbeda tersebut seringkali berdampak konflik karena saling menyalahkan dan adanya keinginan bertahan dan yang mengalahkan (dominasi). Dalam fenomena seperti ini, apakah adat tradisi Sasak yang sudah lama mengakar dan diperaktekkan harus dihapus karena tidak sesuai dengan Islam? Ataukah ada semacam rasionalitas kultural yang melahirkan beberapa alteratif yang bisa dipraktekkan dan menjadi budaya baru?

Persentuhan Islam dengan kebudayaan dan tradisi Sasak berawal dari masuknya agama Islam ke Lombok pada abad ke-14. Keberadaan Suku Sasak di Pulau Lombok sudah lama dikenal dalam sejarah sejak berabad-abad silam. Di dalam kitab Negara kartanegara karya pujangga jawa terkenal di abad ke 14 Mpu Prapanca (1365), nama pulau Lombok sudah disebutnya di dalam pupuh XIV, bait 3 dan 4 sebagai Lombok Mirah, karena pulau Lombok adalah termasuk bagian dari kerajaan Majapahit (1293-1478). ${ }^{3}$ Suku Sasak konon datang dari sebelah Barat Daya India atau Burma dalam gelombang kepindahan mereke ke Indonesia.

Penerimaan Islam bagi orang Sasak, disebabkan oleh beberapa alasan. Pertama, telah tertanam benih-benih agama pada masyarat. Kedua, ajaran Islam dianggap mirip dengan kepercayaan lama yang mereka anut, seperti percaya terhadap

\footnotetext{
${ }^{3}$ Solichin Salam, Lombok Pulau Perawan Sejarah dan Masa depannya (Jakarta: Kuning Mas,1992), 5.
} 
hal gaib dan kekuatan alam. Ketiga, nilai ajaran Islam dianggap benar membawa ajaran kebenaran.

Pertemuan antara dua kebudayaan itu melahirkan dua model relasi dan situasi, dominasi dan integrasi. Dalam dominasi, tingkat perubahan tergantung pada seberapa kuatnya tekanan nilai-nilai luar masuk ke dalam, dan seberapa kuatnya kekuatan internal menahan tekanan tersebut. Model integrasi/akulturasi merupakan pertemuan yang harmonis antara outsider dan insider, misalnya antara Islam dengan kebudayaan lokal; modernitas dengan lokalitas; dan antara kebudayaan global dengan kebudayaan lokal. Hubungan akulturasi atau integrasi terjadi karena adanya dua kekuatan yang saling mempengaruhi dan saling mewarnai satu sama lain, atau istilah Abdurrahman Wahid, sebgai "pribumisasi Islam."

Model interaksi merupakan model adaptasi terbaik dalam konteks hubungan Islam dan kebudayaan lokal. Kelembagaan adat dan agama menjalankan fungsinya secara harmonis dan saling melengkapi. Agama Islam diterima sebagai agama masyarakat, tetapi tidak berarti kontruksi tradisi dan nilai adat yang telah dianut sebelumnya ditinggalkan secara total.

Berkaitan dengan tradisi mengharukan perkawinan anak gadis bangsawannya dengan laki-laki bangsawan mengandung nilai pemeliharaan kesesuaian antara pasangan sebagai langkah preventif terhadap ketidakharmonisan rumah tangga yang tidak jarang disebabkan oleh ketidaksesuaian. Hal ini semakin jelas ketika kelompok bangsawan mempunyai keharusan tanggungjawab besar meliput kehormatian istrinya, ekonomi, keamanan dan kesejahteraan istrinya dan keluarga.

Dalam Islam, dengan teori kafa > abnya, telah melihat hal tersebut, keharusan kesepadanan dalam pasangan terutama suami terhadap istri dan bila terjadi penipuan bahwa si calon suami tidak sepadan maka si perempuan boleh menolak untuk memberlangsungkan pernikahannya. Kesepadanan dalam agama, kekayaan, pendapatan, kesejahteraan, keturrunan, kedudukan, menjadi kewajiban si suami yang mempunyai teanggungjawab besar terhadap istri dan keluarga, menjadi langakh alternative untuk mendapat keluarga yang sakinah, mawadah dan rahmah (kebahagiaan), dan langkah preventif terhadap factor-faktor yang menghambat tujuan pernikahan dan kekeluargaan tersebut, sehingga dengan kehadiran si suami menjadi 
simbol kebahagiaan dan kesejahteraan, bukan malah menjadi orang ketiga dalam keruhnya keluarga.

Berdasar pada rialitas tersebut, maka penelitian tentang Islam pada masyarakat Sasak sangat penting untuk dilakukan. Hal ini didasarkan pada asumsi bahwa masyarakat Sasak sangat terbuka terhadap suatu yang bisa mengubah kehidupannya, seperti yang terlihat jelas dalam tradisi pernikahan di kalangan bangsawan Sasak. Mereka juga tetap setia melakukan aktifitas adat tradisi yang bercorak Islam lokal yang diwariskan secara tradisi (turun temurun).

\section{Tinjauan Umum Tentang Pernikahan Dalam Islam}

\section{Pengertian dan Tujuan Pernikahan}

Pengertian, Allah SWT telah menciptakan pria dan wanita agar dapat berhubungan satu sama lain, saling mencintai, menghasilkan keturunan, serta hidup bersama secara damai yang sesuai dengan perintah Allah SWT dan petunjuk Rasulullah.

Sehubungan dengan adanya akibat yang penting dari hidup bersama, maka masyarakat memerlukan peraturan-peraturan untuk mengatur tentang hidup bersama antara seorang pria dan seorang wanita sebagai suami istri. Hal-hal yang perlu diatur yaitu antara lain mengenai syarat-syarat untuk dapat hidup bersama, pelaksanaan hakhak dan kewajiban, kelanjutan dan mengenai terhentinya hidup bersama tersebut. Keseluruhan aturan-aturan hukum yang menentukan prosedur yang harus dilalui beserta ketentuan hukum yang menentukan hak-hak dan kewajiban serta kelanjutannya dan juga mengenai terhentinya perkawinan akan menimbulkan suatu mengenai ikatan antara seorang pria dan seorang wanita, maka penulis akan menjelaskan tentang perkawinan dari tinjauan hukum Islam.

Istilah perkawinan dalam Islam disebut nikah atau ziwaj. Kedua istilah ini dilihat dari arti katanya dalam bahasa Indonesia ada perbedaan, sebab kata 'nikah' berarti hubungan seks antara suami-istri sedangkan 'ziwaj' berarti kesepakatan antara seorang pria dan seorang wanita yang mengikatkan diri dalam hubungan suami-istri untuk mencapai tujuan hidup dalam melaksanakan ibadat kebaktian kepada Allah. 
Menurut Prof. Ibrahim Hosen, nikah menurut arti asli dapat juga berarti aqad, dengannya menjadi halal hubungan kelamin antara pria dan wanita, sedangkan menurut arti lain ialah bersetubuh (Syafi'i). ${ }^{4}$

Dialah yang menciptakan kamu dari satu zat dan daripadanya Dia menciptakan istrinya agar Dia merasa senang (QS VII : 189) Al A'raaf (tempat tertinggi). Jadi, menurut Al Qur'an, Perkawinan adalah menciptakan kehidupan keluarga antara suami istri dan anak-anak serta orang tua agar tercapai suatu kehidupan yang aman dan tentram (sakinab), pergaulan yang saling mencintai (mawaddah) dan saling menyantuni (rahmah). ${ }^{5}$

Dalam Kompilasi Hukum Islam, Pasal 2 disebutkan bahwa : perkawinan menurut Hukum Islam adalah pernikahan yaitu akad yang sangat kuat atau mitsaqan galidzan untuk mentaati perintah Allah dan melaksanakannya merupakan ibadah.

Dari pengertian tersebut dapat dijelaskan bahwa perkawinan menurut Hukum Islam adalah suatu kesepakatan atau perjanjian antara pria dan wanita yang mengikatkan dirinya dalam hubungan suami istri agar dapat menghalalkan hubungan kelamin guna mendapatkan keturunan dan mencapai tujuan hidup dalam melaksanakan ibadah kebaktian kepada Allah SWT yang disertai dengan hak dan kewajibannya masing-masing.

Tujuan, tujuan perkawinan disebutkan dalam Kompilasi Hukum Islam pada Pasal 3, yaitu : "Perkawinan bertujuan untuk mewujudkan kehidupan rumah tangga yang sakinah, mawaddah dan rahmah".

Sedangkan tujuan perkawinan menurut hukum Islam terdiri dari : Berbakti kepada Allah; Memenuhi atau mencukupkan kodrat hidup manusia yang telah menjadi hukum antara pria dan wanita itu saling membutuhkan; Mempertahankan keturunan umat manusia; Melanjutkan perkembangan dan ketentraman hidup rohaniah antara pria dan wanita; Mendekatkan dan saling menimbulkan pengertian antar golongan manusia untuk menjaga keselamatan hidup. ${ }^{6}$

Karena itu para pihak perlu meneliti lebih dahulu lain jenisnya sebelum melangsungkan perkawinan terutama mengenai agama dan keimanannya, moralitas,

\footnotetext{
${ }^{4}$ Ibrahim Hosen, Figh Perbandingan dalam Masalab Nikah dan Rujuk (Jakarta: Ihya Ulumuddin,1971), 65.

${ }^{5}$ Sajuti Thalib, Hukum Kekeluargaan Indonesia (Jakarta: UI Press, 1974), 47.

${ }^{6}$ R. Abdul Djamali, Rumah Sejabtera (Jakarta: 1989), 75.
} 
keturunan, keelokan dan daya pikirnya. Meneliti lebih dulu termasuk unsur penting, karena agama dan iman merupakan unsur pokok yang dapat menentukan kelangsungan hidup baik dalam keluarga.

\section{Syarat dan Rukun Perkawinan}

Syarat, Yang dimaksud dengan syarat, ialah segala sesuatu yang telah ditentukan dalam hukum Islam sebagai norma untuk menetapkan sahnya perkawinan sebelum dilangsungkan.

Syarat-syarat yang perlu dipenuhi seseorang sebelum melangsungkan perkawinan menurut R. Abdul Djamali yang dikutip dalam bukunya Hukum Islam, ada enam yaitu : Persetujuan kedua belah pihak tampa paksaan, Dewasa, Kesamaan agama Islam, Tidak dalam bubungan nasab, Tidak ada bubungan susunan atau rad\{a>'ab, Tidak semenda atau mus $\{a>$ barah

Selain syarat yang dikemukakan di atas, ada syarat-syarat khusus bagi seorang yang nantinya akan menjadi keluarga sebelum melangsungkan perkawinan. Syaratsyarat khusus itu ialah : a. Pihak pria tidak boleh mempunyai istri lebih dari empat orang ketika akan melangsungsungkan perkawinan. b. Perkawinan poligami tidak boleh dirangkap antara istri yang masih ada hubungan darah dengan calon istri berikutnya, seperti kakak beradik dalam bersamaan menjadi istri-istri seorang pria. c. Tidak ada perceraian "li'an", artinya antar suami-istri terdahulu tidak bercerai karena sumpah sebagai akibat suami menuduh istri berbuat serong atau tuduhan istri bahwa suami berbuat serong. $d$. Calon pengantin wanita tidak dalam ikatan perkawinan. e. Calon istri tidak dalam masa iddah, atau dalam jangka waktu tunggu.

Rukun-rukun Perkawinan, rukun ialah segala sesuatu yang ditentukan menurut hukum Islam dan harus dipenuhi pada saat perkawinan dilangsungkan. Adapun rukun perkawinan diatur dalam Kompilasi Hukum Islam. Di dalam Pasal 14 disebutkan bahwa untuk melaksanakan perkawinan harus ada : Calon suami dan calon istri, Wali nikah, Dua orang, saksi, dan Ijab dan qabul. Untuk lebih jelasnya.

Adapun syarat-syarat yang harus dipenuhi oleh kedua mempelai adalah : a) Telah baligh dan memenuhi kecakapan yang sempurna. b) Berakal sehat dan tidak mengalami gangguan, baik jasmani maupun rohani. c) Tidak karena paksaan. d. Bagi calon suami dan calon istri yang akan melangsungkan perkawinan, tidak terdapat halangan perkawinan sebagaimana diatur dalam Pasal 18 Bab IV KHI. 
Wali ialah orang yang berhak menikahkan anak perempuan dengan pria pilihannya. Mengenai masalah perwalian, di Indonesia menganut ajaran Syafi i yang mengatakan perlu adanya wali nikah bagi pihak wanita, dan wali merupakan salah satu rukun yang harus ada dalam perkawinan. Tanpa adanya wali nikah maka perkawinan tidak sah. Dasar hukum yang dipergunakan antara lain Hadis riwayat Ibnu Majah dan Daruquthni, kitab Musnad Syafi'i:

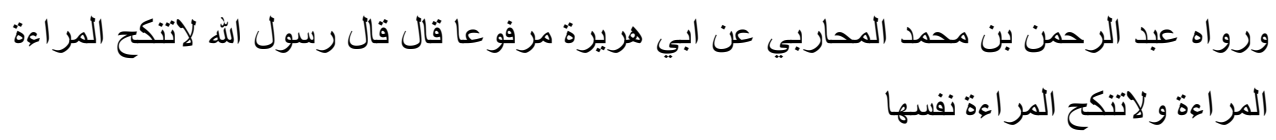

"Jangan perempuan menikahkan perempuan yang lain dan jangan pula menikahkan perempuan akan dirinya sendiri”

Karena kedudukannya yang sangat penting dan menentukan, maka tidak sembarangan orang dapat menjadi wali nikah. Pasal 20 ayat (1) KHI menyebutkan bahwa yang bertindak sebagai wali adalah laki-laki yang memenuhi syarat hokum Islam, yaitu muslim, aqil dan baligh.

Adanya saksi dalam akad nikah menurut Imam Syafi`I adalah suatu keharusan dalam perkawinan, karena saksi dalam perkawinan sangat diperlukan untuk memberikan kesaksian bahwa perkawinan itu benar-benar dilakukan oleh pihak-pihak yang berkeinginan.

Dan kedua orang saksi dibawa oleh masing-masing pihak asalkan memenuhi syarat-syarat seperti yang diwajibkan kepada wali. Dua orang saksi hendaknya laki-laki; tetapi kalau tidak ada, wanitapun diperkenankan hanya jumlahnya harus 4 orang. Dasar hukum perbandingan jumlah itu kalau dililiat dari makna anak kalimat terakhir dari Surah (2) Al-Baqarah ayat 228 yang menyatakan : "Perempuan itu mempunyai hak yang sama dengan laki-laki, tetapi laki-laki mempunyai derajat yang lebih tinggi dari perempuan.

Akad nikah adalah pernyataan sepakat dan pihak calon suami dan pihak calon istri untuk mengikatkan diri mereka ke dalam tali perkawinan dengan menggunakan sighat akad nikeah.

Ijab ialah pemyataan penyerahan dari pihak wanita yang biasanya dilakukan oleh wali calon mempelai wanita atau wakilnya dengan maksud bahwa calon mempelai wanita bersedia dinikahkan dengan calon mempelai pria, sedangkan qabul ialah pemyataan penerimaan yang sah atau jawaban pihak calon mempelai pria atas 
ijab calon mempelai wanita, yang intinya bahwa calon mempelai pria menerima kesediaan calon mempelai wanita menjadi istrinya yang sah.

Kalau syarat-syarat dan rukun-rukun perkawinan itu telah dipenuhi, maka sahlah perkawinannya dan para pihak saat itu berubah status sebagai suami-istri. Mereka hidup dalam satu kesatuan yang dinamakan keluarga. Dan sejak saat itulah timbul hak dan kewajiban sebagai suami-istri.

\section{Kafa'ah dalam Pernikahan Islam}

Dalam ajaran Islam, perkawinan merupakan perbuatan untuk menjalankan perintah Allah sebagai bentuk ketaatan hamba kepada Penciptanya, perkawinan juga merupakan wujud dari menjalankan sunah Rasul-Nya, yaitu membangun suatu kehidupan rumah tangga yang sah menurut Islam untuk mendapatkan kehidupan yang sakinah, mawaddah dan rahmah (kebahagiaan), baik bagi pelaku perkawinan itu sendiri, anak turunan, kerabat, serta masyarakat.

Untuk mencapai tujuan tinggi dan mulia tersebut, khususnya bagi pria harus mempersiapkan diri sedini dan sematang mungkin dalam segala segi, ${ }^{7}$ mengingat mereka akan menjadi sosok pemimpin kecil dalam lingkup keluarganya nanti. Nabi saw. Mengganjurkan umatnya untuk menikah bila sudah mampu, mampu dari segi ekonomi, mampu dari segi mental, mampu psikologi dan lain-lain yang mendukung pemenuhan dan ketentraman berumah tangga. Dalam masalah perkawinan, dalam Islam, sebelum menikah, selain mempertimbangkan hal-hal yang bersifat nilai (agama), juga penting mempertimbangkan hal-hal yang diluar nilai tersebut, seperti kekayaan (ekonomi), keturunan, kecantikan atau kegagahan, inilah yang dikenal dengan pernikahan sekufa' (konsep kafa> 'ah).

Kafa $>$ 'ah merupakan hasil produk manusia dalam Hukum Perkawinan Islam, menurut bahasa ia bermakna al-tasa $>$ wi (comparability, kesebandingan) adalah aturan tentang kesesuaian dan kesebandingan seorang laki-laki dengan calon istri dan keluarga calon istri dalam beberapa hal tertentu. ${ }^{8}$ konsep kafa $>$ 'ah adalah untuk kemaslahatan perkawinan -yang bersifat sosiologis-, yaitu untuk menghindarkan adanya cela dan bahaya, terutama yang bersifat sosial, yang mungkin timbul terhadap

${ }^{7}$ Rahmat Hakim, Hukum Perkawinan Islam (Bandung: Pustaka Setia, 2000), 13.

${ }^{8}$ Muhammad Husayn al-Zahabi, al-Syari>'ah al-Isla>miyyah bayna Maza > bib Abl al-Sunnab wa Mazhab alJa'fariyyah, cet. II (Mesir: Maktabah da>r al-Ta'li, 1968), hlm. 129 dan Muhammad Abu Zahrah, alAbwa > l al-Syakhsiyyah, cet. II (tt.: Da>r al-Fikr al-Arabi, 1957), 156. 
diri istri dan keluarga istri sebagai akibat masuknya seorang laki-laki ke dalam kelurga. Tujuan lebih jauh yang ingin dicapai dengan aturan kafa $>$ 'ab ini adalah tergapainya cinta, kasih sayang, pergaulan yang baik, tukar-menukar pemikiran secara seimbang, dan keharmonisan rumah tangga antara suami istri yang tercipta karena kedudukan mereka yang secara sosial seimbang dan sebanding. ${ }^{9}$

$K a f a>$ 'ab dalam perkawinan berarti kesepadanan atau kesetaraan antara status suami dengan istri, dengan menitikberatkan pada unsur kehormatan (al-hasab), agama $($ al-di $>n)$, keturunan (al-nasab), keluarga (al-bayt) dan sebagainya. Kemudian dianggap urgen karena diharapkan mampu untuk menjaga keharmonisan serta mencegah timbulnya aib yang dapat merugikan pihak wanita, yang bukan tidak mungkin menjadi korban sia-sia dalam bentuk penderitaan lahir dan batin. ${ }^{10}$ Oleh karenanya ukuran ke-kufu'-an ada pada pihak laki-laki, bukan pada wanita. Laki-laki yang dikenai persyaratan itu hendaknya se-kufu' dengan wanitanya, bukan sebaliknya yaitu wanitanya yang harus se-kufu' dengan laki-laki. ${ }^{11}$

Sebagian besar fuqaha >' sepakat bahwa pemenuhan syarat kafa >'ah di dalam sebuah perkawinan, merupakan hak bagi perempuan yang bersangkutan dan hak bagi para walinya secara timbal balik. Apabila si perempuan menikahkan dirinya sendiri (atau dinikahkan oleh salah satu walinya) dengan laki-laki yang tidak sekufu dengannya, maka perempuan yang bersangkutan memiliki hak untuk mengajukan fasakh terhadap perkawinan yang sudah terjadi. ${ }^{12}$

Menurut Abu Zahrah dalam al-Ahwa>l al-Syakhsiyyah, pihak yang memiliki keharusan untuk memenuhi persyaratan kafa $>$ 'ah, menurut jumhur ulama' adalah calon suami, bukan calon istri. Hal ini didasarkan kepada alasan bahwa seseorang laki-laki tidak akan mendapatkan cela dari masyarakat apabila memperistri seseorang perempuan yang memiliki status sosial lebih rendah darinya. Sebaliknya, apabila seseorang perempuan bersuami laki-laki yang tidak sekufu dengannya maka

\footnotetext{
${ }^{9}$ Lihat Muhammad Zayd al-Ibyani, Syarh al-abka $>m$ asy syari $>$ ah fi $>$ al-ahwa $>$ lasy Syahsiah li Muhammad Qodri basya (Bairut: Maktabah al- Nahdah, t.t.), hlm. 94-95. Bandingkan dengan Mahmud Shaltut yang menilai bahwa kafa >'ah adalah salah satu pilar bangunan keluarga yang islami, lihat Mahmud Shaltut, al Islam, Aqidah wa Syari >'ah, cet. 1 (ttp: da>r al Kholam, 1966), 159.

${ }^{10}$ Djamaluddin Assagaf, Kafa >'ah, hlm. 11. Dan Hasyim Assagaf, Derita Putri-Putri Nabi: Studi Historis Kafa >'ab Syrifah (Bandung: PT. Remaja Rosdakarya, 2000 M), 7.

11 Muhammad Jawad Mughniyah, Fiqih, hlm. 349-350.

12 Muhammad Abu Zahrah, al-Ahwa >l al-Syakhsiyyah, cet-III (ttp : da>r al-Fikr al-'Arabi> 1377/1957, 165-168.
} 
perempuan tersebut dan seluruh keluarganya akan mendapatkan cela dari masyarakat. ${ }^{13}$ Oleh karena itu perempuan bisa menikah dengan laki-laki yang mempunyai derajat yang lebih tinggi, namun tidak bisa menikah dengan laki-laki yang mempunyai derajat yang lebih rendah darinya. Sementara laki-laki boleh menikah dengan perempuan yang memiliki derajat lebih rendah, namun tidak bisa menikah dengan perempuan yang memiliki derajat lebih tinggi darinya.

Kafa $>$ 'ah dalam pandangan mazhab hanafi diartikan sebagai persamaan atau kesesuaian laki-laki dengan perempuan yang akan menjadi istrinya. Secara umum keberadaan kafa $>$ 'ah dalam perkawinan menurut mazhab ini dijadikan sebagai syarat luzum bagi perkawinan ${ }^{14}$ dan memiliki hubungan erat dengan wali nikah.

Dalam Mazhab Maliki, Kafa >'ab adalah keserupaan atau kesebandingan antara seseorang calon suami dengan calon istrinya dalam dua hal, pertama, keberagamaan calon suami, yang ditandai dengan keadaan dirinya sebagai orang Islam yang tidak fasikh, kekdua, terbebasnya calon suami dari berbagai aib yang dapat menimbulkan adanya khiyar bagi calon istrinya, seperti gila, penyakit kusta atau lepra. ${ }^{15}$ Menurut mazhab maliki kafa $>$ 'ah merupakan syarat syah ${ }^{16}$ bagi sebuah perkawinan.

Dalam Mazhab Syafi'I Kafa>'ah adalah sesuatu yang dapat menyebabkan malu apabila tidak terpenuhi, yaitu kesembandingan kondisi calon pengantin baik yang berkenaan dengan kondisi kesempurnaan maupun kekurangan mereka. Termasuk di dalamnya keterbatasan seorang calon pengantin dari aib-aib nikah. ${ }^{17}$ Penenuhan syarat kafa >'ah dalam pernikahan adalah sebuah keniscayaan, sebab dengan itu pernikahan dapat diharapkan untuk menghasilakan kebaikan serta tidak mengakibatkan adanya kekurangan dan ketercelaan pada diri calon istri dan para walinya. ${ }^{18}$ Dengan demikian kedudukan kafa $>$ 'ah dalam perkawinan menurut mazhab Syafi'i adalah sebuah keniscayaan yang bersifat social.

Setelah mengetahui uraian kafa $>^{\prime} a b$ menurut pandangan mazhab fikih di atas dapat difahami bahwa rumusan kriteria kafa $>$ 'ab sama sekali tidak bermaksud

\footnotetext{
${ }^{13}$ Ibid, 163.

${ }^{14}$ Wabah al-Zuhayli, al-Fiqh al-Isla $>$ mi $>$ wa adilatubu, cet. III (Damaskus: Da $>$ r al-Fikr al-'Arabi $\left.>1989\right)$, VII: 235.

15 'Abd al-Rahma al-Jaziri, Kita $>b$ al-Fiqh'Ala $>$ Maza $>$ bib al-Arba, ah, IV : 58

${ }^{16} \mathrm{Abu}$ 'Abbs Ahmad bin 'Umar al-dayrabi al-Syafi'I, Abka $>m$ al-Zawa $>j$ 'ala $>$ al-Maza $>$ bib al-Arba'ah (Beirut: Da $>$ r al-Kutub al-'imiyyah 1986), 159.

${ }^{17}$ Ibid, IV : 58-59

18 Al-Dayrabi al-Syafi'I, Abka $>m$ al-Zawa $>$ j, 155.
} 
melebihkan atau mengutamakan seseorang atau satu suku dengan suku lain atau satu bangsa dengan bangsa lain. Sebab jika hal ini terjadi, maka jelas-jelas bertentangan dengan spirit al-Qur'an dan sunnah Nabi. Menurut Mu'ammal Hamaidi ${ }^{19}$ paling tidak ada dua tujuan pokok mengenai keberadaan konsep kafa > 'ah, pertama, sebagai usaha untuk menciptakan keluarga atau rumah tangga yang bahagia dan sejahtera. Kedua, merupakan usaha untuk menghindar dari kesusahan dan malapetaka perkawinan. Dengan bertemunya pasangan yang serasi dan sepadan, diharapkan kehidupan keluarga akan mampu menjalankan roda rumah tangga dengan baik, sebaliknya pasangan yang tidak sepadan dikhawatirkan akan melahirkan rumah tangga yang tidak tenteram. Dengan demikian dari segi unsurnya, kafa $>$ 'ah hanya hubungan unsur sosial, yang dengan itu diharapkan suami dan istri dapat menjalankan bahtera rumah tangga dengan bai menuju keluarga yang sejahtera dan bahagia.

\section{Lombok dan Tradisi Pernikahannya}

Proses Pelaksanaan Merarik (perkawinan)

Seperti halnya perkawinan pada umumnya, merarik juga dilakukan melalui tahapan-tahapan tertentu yang didasarkan pada ketentuan adat. Tahapan-tahapan tersebut meliputi: proses perkenalan, lari bersama untuk kawin dan proses penyelesaianny serta aqad perkawinan.

Masa perkenalan dan pemilihan jodoh melalui suatu lembaga adat yang disebut midang. Midang adalah kunjugan seorang laki-laki kepada seorang perempuan dengan maksud untuk mengadakan perkenalan, pendekatan dan menjalin hubungan cinta.

Setelah beberapa kali midang dilakukan, barulah si pemuda menanyakan apakah perempuan pujaannya itu benar-benar mencintainya dan bersedia menjadi istrinya?. Jika tawarannya diterima, barulah terjadi beberayean. Jika dua sejoli sudah sepakat untuk kawin, maka selanjutnya yang dilakukan adalah melarikan si gadis dari lingkungan orangtua serta keluarganya. Tidakan ini disebut merarik atau melaiang. ${ }^{20}$

Di bale penyeboan, kedua calon mempelai terikat dengan berbagai ketentuan adat yang ketat. Misalnya mereka tidak boleh tidur bersama di satu tempat tidur

${ }^{19} \mathrm{Mu}$ 'ammal Hamidy, Perkawinan dan persoalaya, bagaimana cara pemecahannya dalam Islam (Surabaya; Bina Ilmu, 1980), 61-62.

${ }^{20}$ Departemen Pendidikan dan Kebudayaan, Adat Istidat., 35. 
sampai benar-benar telah menjadi pasangan suami istri yang sah. Demikian juga si gadis tidak boleh menampakkan dirinya di muka umum, lebih-lebih di hadapan keluarganya. Sebab, bila ini dilakukan, pihak keluarganya akan menganggap bahwa si pemuda telah menghinanya karena belum dilakukan pemberitahuan dan berbagai proses adat sebagaimana mestinya. Pelanggaran terhadap ketentuan-ketentuan adat tersebut akan menimbulkan sanksi atau denda adat yang disebut desosan. ${ }^{21}$

Dengan terjadinya merarik atau melaiang, berbagai tindakan adat yang mengarah pada terjadinya perkawinan dalam arti yang sebenarnya mulai dilakukan oleh kedua belah pihak. Tindakan-tindakan tersebut meliputi sejati, selabar, dan ngawinang.

\section{Selabar}

Setelah selesai sejati, dua atau tiga hari berikutnya dilakuakan selebar, yaitu permintaan pihak laki yang diwakilkan oleh kliang dan pengulu kepada orang tua wali si perempuan untuk menikahkan anak putrinya. Dalam kaitan ini, orangtua gadis diminta bersedia memberikan persetujuan dan perwaliannya bagi perkawinan anaknya. Atas dasar inilah, selabar disebut juga dengan bait wali (mengambil wali).

Tidak diragukan bahwa keberadaan wali dalam adat perkawinan Sasak sangat penting dan menentukan. Artinya, dilangsungkan atau tidaknya suatu perkawinan ditentukan oleh ada atau tidak adanya wali. Tidak ada wali berarti tidak ada perkawinan.

Salah satu bentuk pembayaran dalam adat perkawinan Sasak yang harus disepakati adalah aji krama, yaitu sejumlah pembayaran yang telah ditetapkan oleh adat sebagai simbolisasi 'harga' dan status social dari pasangan pengantin dan setiap keturunan yang akan mereka lahirkan. ${ }^{22}$ Aji krama berasal dari bahasa sansekerta yang menurut sebuah interpretasi berarti 'adat yang tinggi.' Ada juga menghaluskan 'aji' dengan arti 'harga' sebagaimana ada dalam bahasa Sasak sehari-hari. Interpretasi ini menyampaikan sepotong 'nilai adat' atau 'tingkatan adat' yang lebih prosaik. ${ }^{23}$

${ }^{21}$ Departemen Pedndidikan dan Kebudayaan NTB, Adat Istiadat Daerah Nusa Tenggara Barat (Mataram: Proyek Penelitian dan Pencatatan Kebudayaan Daerah, 1977-1978), 155.

${ }^{22}$ M. Mimbarman Dalem, Lombok Selatan dalam Pelukan Adat Istiadat Sasak (Lombok: Departemen Pendidikan dan Kebudayaan, t.t.), 53.

${ }^{23}$ Jhon Ryan Bartholomew, Alif Lam Mim., 247. 
Mengingat fungsinya itu, maka jumlah aji krame berbeda-beda untuk tiap-tiap tingkatan masyarakat. Misalnya, golongan bangsawan atas mempunyai: aji krame 99 yang disimbolkan dengan sejumlah barang tertentu seperti 68 potong kain, sebilah keris, sepetak tanah, tigapuluh ribu uang tunai dan sebagainya. Golongan bangsawan menengah mempunyai aji krame 66 yang terdiri dari 44 potong kain, sebilah keris, sepetak tanah dan duapuluh ribu uang tunai. Sedangkan golongan jajar karang mempunyai aji krame 33 yang berupa 21 potong kain, sebilah keris, seperak tanah, dan sepuluh ribu uang tunai. ${ }^{24}$ Benda-benda aji krama ini memiliki makna simbolik yang berbeda-beda. Kain misalnya melambangkan kesamggupan mempelai laki-laki untuk memberikan kebutuhan sandang kepada mempelai perempuan serta kepada semua anak-anaknya yang akan lahir. Keris melambangkan kesanggupan mempelai laki-laki untuk membela mempelai perempuan dalam kewajibannya sebagai pelindung rumah tangga. Sawah melambangkan kesanggupan mempelai laki-laki untuk memenuhi kebutuhan pangan dan uang tunai melambangkan kesanggupan untuk memberikan belanja dan kebutuhan rumah tangga. ${ }^{25}$

Di samping aji krame, pihak perempuan juga biasanya meminta pembayaran lain yang disebut pisuke, berupa uang atau barang-barang berharga lainnya. Sesuai artinya, yakni 'penyenang' atau 'yang menjadikan rela (suke)', pisuke berfungsi sebagai penghibur rasa sedih orangtua yang ditinggal pergi oleh anak gadisnya. Ia juga menjadikannya rela jika anaknya itu kawin dengan laki-laki yang telah melarikannya. ${ }^{26}$ Dengan demikian, pisuke semata-mata merupakan permintaan orangtua untuk dirinya, meski dalam prakteknya, tidak sedikit yang mempergunakannya untuk keperluan kedua mempelai. Misalnya untuk membelikan mereka barang-barang kebutuhan rumah tangga seperti piring, gelas, kasur dan sebagainya. Inaq Edi, ibu dari seorang gadis yang baru menikah mengatakan, uang pisuke yang diberikan oleh pihak laki-laki, sebagiannya kami gunakan untuk keperluan sendiri dan sebagiannya lagi kami gunakan untuk keperluan anak saya yang baru merarik. ${ }^{27}$

\footnotetext{
${ }^{24}$ M. Mimbarman Dalem, Lombok Selatan., 54.

${ }^{25}$ Ibid.

26 Wawancara dengan Mamik Adi (Tokoh Masyarakat Desa Darmaji, Iwan) pada tanggal 29 Agustus 2011.

${ }_{27}$ Wawancara dengan Inaq Edi dan Bape Murni pada tanggal 24 Agustru 2011.
} 
Besarnya jumlah pisuke sebenarnya berbeda-beda di masing-masing tempat dan dipengaruhi oleh banyak factor, seperti kualitas fisik si gadis, status sosial keluarganya dalam masyarakat, jauh dekatnya jarak pelarian dan sebagainya. Namun demikian, biasanya orangtua akan meminta pembayaran yang tinggi bagi anak gadisnya. Langkah ini bisa jadi merupakan strategi dalam proses negosiasi dan tawar menawar untuk mendapatkan pembayaran yang memadai.

Dengan dicapainya kesepakatan mengenai perwalian, sebagaian besar missi selabar dapat dikatakan telah berhasil. Maka pembicaraan dapat diteruskan kepada rencana perkawinan, terutama yang berkaitan dengan waktu dan tempat pelaksanaan aqad. Namun hal ini bukanlah persoalan yang sulit, karena orangtua gadis biasanya menyerahkan sepenuhnya kepada keluarga pihak laki-laki. Maka berakhirlah acara selabar dan dilanjutkan dengan prosesi ngawinang.

2. Ngawinang

Ngawinang (mengawinkan) atau juga disebut nikahang (menikahkan) merupakan salah satu rangkaian dari upaya penyelesaian kawin merarik menurut adat Sasak. Prosesi ini dilakukan setelah selabar, yaitu setelah diberikannya persetujuan dan perwalian oleh orangtua perempuan. Tujuannya adalah untuk memberikan status hukum berdasarkan agama atas hubungan kedua calon mempelai, sehingga mereka dapat bergaul dan berhubungan secara sah sebagai suami istri. H. Suparman, S.Pd., seorang pegawai KUA Kopang mengatakan, tampa adanya ngawinang atau nikahang kawin lari tetap dipandang tidak sah. ${ }^{28}$

Dalam prakteknya, ngawinang atau nikahang diselenggakan di rumah keluarga pihak laki-laki dengan acara yang sangat sederhana, yaitu sekedar dipenuhinya persyaratan-persyaratan bagi sahnya suatu aqad perkawinan menurut Hukum Islam. Karena itu, pihak-pihak yang biasanya terlibat adalah wali gadis atau yang mewakilinya, kedua calon mempelai, dua orang saksi, kiai dan pemuka adat serta para undangan dari warga kampung setempat. Di samping itu, hadir juga Petugas Pencatat Nikah (PPN) dari Kantor Urusan Agama (KUA).

Upacara ngawinang juga disertai dengan khutbah nikah oleh tokoh agama mengenai kewajiban yang disyaratkan kepada suami dan istri dalam sebuah

${ }^{28}$ Wawancara dengan H.Ruslan (pegawai KUA) pada tanggal 25 Maret 2012. 
perkawinan. Dalam banyak hal, pelajaran ini diikuti dengan nasehat dari angota keluarga mempelai laki-laki. Upacara ngawinang akhirnya ditutup dengan doa yang diiringi dengan jamuan makan dan minum. Setelah semuanya selesai, setiap orang kemudian pulang ke rumah masing-masing.

1. Upacara-upacara Perkawinan

Merupakan tradisi bagi masyarakat Sasak bahwa suatu perkawinan diikuti dengan penyelenggaraan upacara adat yang meriah. Upacara ini dalam bentuknya yang paling sempurna terdiri dari tiga tahapan: sorong serah, pembayunan dan nyongkolan. Selain sorong serah dan pembayunan yang dipraktekkan oleh masyarakat Sasak (terutama kaum bangsawan) sebagai seremoni adat, juga sebagai sarana mempertahankan status sosial bagi bangsawan.

a. Sorong serah dan pembayunan

Sorong serah adalah sebuah kata Sasak yang berasal dari sorong yang berarti mendorong atau memberikan, dan serah yang berarti menyerahkan. Sorong serah merupakan suatu seremoni perkawinan adat yang diadakan untuk memberikan dan menyerahkan aji krama serta benda-benda pelanggaran adat yang terjadi sejak masa pelarian sampai saat pelaksanaan seremoni. Penyerahan aji karma adat ini merupakan simbolisasi dari tingkat status sosial kedua mempelai, terutama mempelai perempuan serta anak keturunan yang dilahirkannya. ${ }^{29}$

Upacara sorong serah berfungsi sebagai sarana pengumuman, publikasi dan perkenalan tentang suatu perkawinan. Juga sebagai permakluman kepada masyarakat tentang status kedua mempelai, terutama mempelai wanita serta anak-anak yang lahir dari perkawinan tersebut.

Sorong serah secara tipikal dilaksanakan secara lansung ketika prosesi nyongkolang tiba di rumah mempelai perempuan dan seringkali dibarengi dengan upacara pembayunan. Seremoni ini biasanya dilaksanakan di rumah orang tua mempelai perempuan. Namun bisa juga di rumah kerabat terdekat seperti di rumah paman atau kakak mempelai perempuan yang telah kawin. Di tempat ini, ayah mempelai perempuan, keluarga laki-lakinya, ketua adat, keliang kampung dan kiai serta anggota-anggota komunitas mempelai perempuan telah menunggu datangnya

${ }^{29}$ Tatiek Kartikasari (ed), Upacara Tradisional Sorong Serah dan Nyongdol dalam Adat Perkawinan Sasak di Lombok (Lombok: Publikasi Proyek Inventarisasi dan Pembinaan NIlai-nilai Budaya, 1991), 14. 
prosesi. Mereka duduk di atas berugak ${ }^{30}$ atau di atas tikar di bawah tenda yang sengaja dibuat untuk itu.

Rombongan sorong serah mempelai laki-laki pun tiba. Mereka terdiri dari dua orang pembayun yang menggunakan pakaian adat lengkap sepeerti kain batik, sapuk (ikat kepala), dodot (sejenis kain sarung) dan sebilah keris yang diselipkan dipinggang. Di belakangnya terdapat orang-orang yang membawa aji krama dan barang-barang lainnya sebagai bingkisan bagi keluarga mempelai perempuan. Tidak jauh di belakangnya lagi terdapat rombongan nyongkolan yang terdiri dari mempelai perempuan, mempelai laki-laki dan anggota-anggota kampung atau desanya.

Setelah saling bertukar pembicaraan yang secara simbolik mengindikasikan status pasangan itu, maka penyerahan aji krama dan denda-denda adat lainnya. Peristiwa ini menandai penerimaan dan pengakuan secara resmi keluarga mempelai perempuan terhadap status kedua mempelai tersebut. ${ }^{31}$ Pembayun beserta rombongannya kemudian dipersilahkan duduk sambil menunggu kehadiran rombongan penyongkol. Dengan datangnya rombongan ini, maka berakhirlah seremoni sorong serah dan pembayunan.

b. Nyongkolan

Nyongkolan, ${ }^{32}$ merupakn prosesi yang paling ramai dalam upacara pernikahan Sasak, di mana semua orang terutama para muda mudi turut bergembira memperolah kesempatan untuk bersenang-senang. Prosesi ini bertujuan untuk kali pertamanya kedua mempelai manampakkan dirinya secara resmi di hadapan orangtua perempuan dan keluarga-keluarganya.

Prosesi nyongkolan yang khas terdiri dari mempelai perempuan dan laki-laki disertai dengan rombongan besar dari desa atau kampung mempelai laki-laki dan kelompok pemusik. Dalam prosesi nyongkolan yang lebih tradisional, kebanyakan anggota-anggota masyarakat yang ikut berpakaian seremonial Sasak. Untuk laki-laki

\footnotetext{
${ }^{30}$ Berugak adalah sebuah bangunan kecil yang terbuat dari kayu dan beratapkan ijuk atau ilalang. Bangunan yang dapat ditemukan di hampir seluruh Lombok ini berada di luar rumah (biasanya di halaman) dan digunakan sebagai tempat duduk bersama tamu dan untuk berteduh. Meskipun ia menyerupai gaya arsitektur yang ditemukan di Bali dan Jawa, namun bangunan ini dianggap sebagai inti dari gambaran rumah-rumah Sasak.

31 Lihat: Mimbarman Dalem, Lombok Selatan., hlm. 57. Tatiek Kartikasari (ed.), Upacara Tradisional Sorong Serah., 29-30. Jhon Ryan Bathlolomew, ALif Lam Mim., 246.

32 Di beberapa tempat "nyongkol" juga disebut dengan "nyondol”. Lihat Titiek Kartikasari, Upacara Sorong Serab dan Nyondol...
} 
menggunakan pakaian kebesaran mereka yang terdiri dari kain batik, sapuk, dodot dan sebilah keris yang diselipkan di pinggang. Sedangkan untuk perempuan tanpa kecuali memakai kebaya yang dipadukan dengan selendang. ${ }^{33}$

Mempelai perempuan disertai dengan rombongan pengiring wanita yang kebanyakan berasal dari daerah mempelai laki-laki dan ditempatkan di bagian barisan depan. Di samping mempelai perempuan adalah inan praja yang bertanggung jawab atas keselamatan perjalanan dan sering membetulkan riasan serta pakaian mempelai perempuan. Sementara itu mempelai laki-laki dipisahkan dari mempelai perempuan dan rombongannya serta mengikuti di belakangnnya semua rombongan laki-laki.

Rombongan besar yang diiringi alat-alat musik tradisional seperti rabana atau gendang belek ${ }^{34}$ ini berangkat dari rumah mempelai laki-laki menuju rumah mempelai perempuan. Adalah biasa jika jarak kedua rumah berdekatan ditempuh dengan perjalanan kaki dan jika berjauhan dengan menggunakan kendaraan. Sepanjang jalanan yang dilalui, para penduduk biasanya berkerumun untuk melihat kedua mempelai sambil menikmati alunan musik yang mengiringi rombongan tersebut. Suasana ini menambah semarak jalannya prosesi nyongkolan.

Setibanya di rumah orangtua mempelai perempuan, rombongan penyongkol dipersilahkan duduk dan berbincang-bincang dalam suasana kekeluargaan. Kedua mempelai kemudian menemui orangtua mempelai perempuan untuk memberikan penghormatan. Pertemuan antara orangtua dan anak ini tidak jarang diliputi suasana haru dan isak tangis. Sebab inilah pertemuan pertamanya sejak si anak meninggalkan rumah orangtuanya untuk kawin. Setelah beberapa saat, akhirnya rombongan penyongkol kembali. Setiap orang kemudian pulang ke rumahnya masing-masing.

Dengan selesainya nyongkolan berakhirlah semua rangkaian upacara adat perkawinan. Kedua mempelai pun telah resmi menjadi keluarga kedua belah pihak sehingga mereka bebas saling mengunjungi.

\footnotetext{
33 Meskipun pakaian adat seperti ini masih dominan dipertahankan, namun ada juga sebagian orang Sasak yang hanya berpakaian biasa-biasa saja dalam prosesi nyongkolan, seperti laki-laki menggunakan baju kemeja, celana panjang dan peci. Sedangkan perempuan menggunakan pakaian Muslim dengan mengenakan kerudung.

${ }^{34}$ Sejak tahun 1990-an, popularitas musik tradisional yang mengiringi prosesi nyongkolan akhir-akhir ini sudah mulai berkurang dan digantikan dengan musik modern, yaitu kombinasi musik-musik modern, seperti marching Band yang berdiri dari alat musik organ dan drums dengan iringan lagu-lagu pop, dangdut dan bahkan lagu barat.
} 


\section{Sistem Stratafikasi Sosial Dalam Masyarakat Sasak}

Dalam masyarakat Sasak, dikenal system stratafikasi sosial ${ }^{35}$ yang ditandai dengan gelar tertentu di awal nama mereka. Ada tiga tingakatan yang terdapat dalam sistem statafikasi sosial Sasak, yaitu; pertama, golongan bangsawan menak atas / perwangse yang berasal dari keturunan raja-raja Sasak, pembesar kerajaan dan keluarga raja-raja. Gelar-gelar yang disandang adalah nenek bagi putra raja, raden dan dinda bagi putra putri keluarga raja.

Tingkatan kedua adalah golongan bangsawan menak menengah yang berasal dari perkawinan campuran antara laki-laki menak atas dengan perempuan jajar karang. Gelar yang dipergunakan adalah lalu bagi laki-laki dan lale atau baiq bagi perempuan. Lapisan terakhir adalah golongan jajar karang, mereka merupakan rakyat biasa dan tidak memiliki gelar kecuali setelah memiliki anak, yaitu bapak atau amaq bagi laki-laki dan inaq bagi perempuan. Di kecamatan Kopang dan bahkan Lombok pada umumnya, lapisan-lapisan tersebut masih tetap dipertahankan. Dari segi kuantitas, golongan bangsawan menak dapat dikatakan sebagai kelompok minoritas. Meski demikian, posisi-posisi penting pemerintahan tertentu, seperti sebagai bupati, camat dan bahkan kepala desa, umumnya dijabat oleh golongan ini.

Dalam kehidupan sehari-hari, antara lapisan-lapisan tersebut terdapat perbedaan dalam sopan santun dan tutur bahasa. Dalam penggunaan bahasa, bahasa Sasak juga mengenal tingkatan bahasa yakni ada tiga tingkatan bahasa yaitu bahasa halus/utama, bahasa madya, dan bahasa biasa, misalnya untuk pengucapan kata makan; mendaran (bahasa utama), bekelor (bahasa madya), dan mangan (bahasa biasa). Pada umumnya para golongan masyarakat yang berasal dari golongan perwangse/menak menggunakan bahasa utama dan sebagian menggunakan bahasa madya dalam kehidupan sehari-harinya, umumnya bahasa utama dipergunakan jika seseorang berbicara dengan orang yang dituakan, sedangkan bahasa biasa umum dipakai oleh orang kebanyakan atau orang biasa dalam kehidupan sehari-hari. Bahasa Sasak terdiri

\footnotetext{
35 Patron klein merupakan system yang dianut oleh masyarakat Sasak dalam system sosial, hal ini dibentuk akibat otoritas kekuasaan, yang mana dipengaruhi oleh penduduk kerajaan Karang Asem Bali terhadap kerajaan-kerajaan yang ada di Lombok. Hasil wawancara dengan Mamik Wiratmaja pada tanggal 21 Maret 2012.
} 
atas beberapa dialek, yaitu: dialek Sasak Pejanggik, Sasak Selaparang, Sasak Bayan, Sasak Tanjong, Sasak Pujut, Sasak Sembalun, Sasak Tebango, dan Sasak Pengantap. ${ }^{36}$

Meskipun terjadi modernisasi dan pemerataan pembangunan di berbagai sektor kehidupan bagi seluruh lapisan masyarakat, system tratafikasi sosial yang ada di Lombok umumnya dan Kopang ksususnya, seperti orang-orang menak dengan jajar karang tersebut masih tetap dipertahankan sampai sekarang. Sekarang ini, mereka telah dapat bergaul dan berhubungan secara timbal balik dengan tanpa mementingkan 'ego' status golongan mereka. Kecuali dalam beberapa hal tertentu saja, seperti 'perkawinan', perbedaan itu masih tetap dan tidak dikikis habis. Misalnya, laki-laki menak boleh mengawini perempuan jajar karang, tetapi sebaliknya laki-laki jajar karang tidak boleh mengawini perempuan menak. Hal ini tampaknya didasarkan pada pandangan bahwa antara laki-laki jajar karang dengan perempuan menak tidak sepadan. Karena itu perkawinan semacam ini sedapat mungkin harus dicegah. Jika ini terjadi, kedua belah pihak kemungkinan besar akan mendapat sanksi yang tidak kecil, sebab mempelai perempuan tidak menutup kemungkinan “te teteb” (dibuang).

Pelestarian stratafikasi sosial tersebut juga nampak jelas dalam adat pelasksanaan adat, ketika melihat prosesi pernikahan di kalangan masyarakat Sasak, dalam prosesi adat perkawinan setiap yang menikah akan mendapat perlakuan dan prosesi yang berbeda sesuai dengan tingkatan sosial yang dimilikinya. Pertama, dalam ajikrama. Ajikrama yang diberikan kepada pihak wanita oleh pihak pengantin laki akan berbeda menurut tingkatan sosialnya, bagi menak atas akan di ajikramakan 99, bagi menak menengah akan diajikramakan 66 dan bagi jajar karang akan diajikramakan 33. Kedua, dalam gantiran atau yang sekarang disebut dengan pisuke. Dalam pisuke, jumlah akan berbeda-beda menurut tingkata sosial dan kehormatannya.

Dalam masyarakat adat manapun, masalah perkawinan bukanlah persoalan antara dua pihak yang akan melakkukan hajat saja, tetapi melibatkan juga seluruh kerabat keluarga, bahkan masyarakat adat. Mengingat perkawinan sebagai ikatan yang menyatukan antara dua pihak yang berbeda, maka pernikahan tidak boleh dilakukan secara diam-diam, tetapi harus terang-terangan dan diumumkan. Terwujudnya

36 Zulyani Hidayah, op. cit., 233. 
perkawinan merupakan idaman setiap orang, tetepi harus memenuhi kriteria pasangan, dalam rangka mencapat keluarga yang aman dan sejahtera, bahagia.

Matoritas masyarakat Sasak tidak sepakat bila agama menjadi satu-satunya keriteria dalam memilih calon pasangan yang akan dipersuntingkan, mereka meyakini banyak aspek-aspek lain yang harus dipenuhi untuk menuju perkawinan tersebut. Baik itu adalah aspek kekayaan, ekonomi, propesi, aspek, kecantikan dan kegagahan, pendidikan, keturunan, aspek kedudukan sosial mempunyai peranan penting dalam mencapai tujuan pernikahan.

Oleh karena itu, tidak mengherankan apabila mayoritas masyarakat masih memegang kukuk tradisi pernikahan yang berdasarkan tingkatan sosialnya. Dalam kasus Baiq Sri Banun (20 tahun), ia harus melupakan indahnya malam pertamanya, karena calon suami yang hendak melamarnya dianggap tidak sekufu dengannya. Pihak keluarga merasa keberatan dan tidak setuju atas rencana pelamaran tersebut sebab perkawinan mereka dianggap menurunkan derajat sosial di masyarakat.

Melihat pernikahan di Sasak dan berikut prosesi adat yang mesti terlaksana, mengindikasikan masifikasi sakralitas pernikahan, dengan media budaya tradisi pernikahan tetap menjadi prosesi sakral yang hanya mampu dilakukan oleh orangorang yang mampu untuk menempuh tangga berumah tangga, hal tersebut menjadi lebih massif kritka Islam mengajarkan pentingnya pematangan persiapan sebelum menikah yang dikenal dengan kafa >'ah.

\section{Akullturasi Islam Dengan Tradisi Pernikahan Masyarakat Bangsawan Sasak Pola-pola akulturasi: dominasi, modifikasi/interaksi, dan rejeksi}

Kedatangan Islam di Lombok, khususnya di Kopang, membawa pengaruh besar bagi penduduk setempat, baik sistem nilai maupun adat istiadatnya, Islam membawa warna baru yang melebur dengan warna yang sudah ada sebelumnya, yaitu warna hinduistik. Bertemuan kedua kebudayaan tersebut melalui proses adaptasi yang harmonis, sehingga meski terjadi konflik, tidaklah terlalu berarti, adanya benih kepercayaan setempat kepada mistik menjadi alasan mudahnya Islam diterima sebagai kepercayaan baru.

Dalam proses pertemuan antara kedua kebudayaan tersebut, yakni Islam dan budaya lokal di Sasak, telah melahirkan model adaptasi, yaitu model dominasi, model modifikasi atau integrasi, dan model resistensi atau rejeksi. Pertama. Model dominasi. 
Model ini ditandai dengan proses massifikasi budaya outsider dan menyingkirkan eksistensi kebudayaan lokal. Dalam hal ini, tingkat perubahan bergantung pada seberapa kuatnya tekanan nilai-nilai luar (Islam) masuk ke dalam, dan seberepa kuatnya kekuatan internal menahan terkanan tersebut. Perubahan total (revolusi) akan terjadi jika penetrasi nilai-nilai luar mempengaruhi sistem ide dalam masyarakat tersebut. ${ }^{37}$ Perubahan sistem ide akan berimplikasi pada perubahan keseluruhan sistem sosial dan budaya masyarakat. ${ }^{38}$

Dalam tradisi pernikahan masyarakat bangsawan Sasak Kopang, tradisi yang didominasi Islam adalah penghapusan tradisi meminum minuman keras ketika beralangsungnya prosesi nyongkolang, penghapusan mantra-mantra yang jelas-jelas mengandung makna kemusrikan, mendahulukan pembahsan masalah agama dari pada masalah adat seperti untuk menentukan apakah si pria dan si wanita tidak mempunyai halangan untuk menikah, seperti karena sepesusuan ataupun semenda. Kedua, model integrasi atau modifikasi. Model ini merupakan pertemuan yang harmonis antara dua kebudayaan yang berbeda.

Model ini bisa terwujud dalam model yang akulturatif seperti mengadopsi budaya Islam dengan memulai mantera-mantera dengan basmalah, dan diakhiri dengan syahadat tanpa menghilangkan mantera itu sendiri. Melakukan resistematika prosesi penyelesaian melaiang yang dimulai dengan kliang, didahului dengan hal-hal yang bersifat agama, baru kemudian diikuti dengan prosesi adat, disini adat tetap dipertahankan, hanya saja agama masuk dan didahulukan, dalam prosesi selabar, penbulu (tokoh agama) menyelesaikan yang berkaitan dengan agama, seperti mencari tahu hal-hal yang bisa saja menghalangi kebolehan pernikahan pria dan wanitanya menurut agama Islam seperti sepesusuan dan lain-lainnya, meminta wali untuk menyegerakan mengaqadkan anak perempuannya, baru setelah itu disusul dengan penyelesaian adat seperti sanksi pelanggaran adat seperti melarikan si wantia pada siang hari.

Penentuan jumlah ajikrama, dan penentuan jumlah pisuke, dalam prosesi ini, Islam tidak mengikis habis adat yang ada, akan tetapi tetap utuh, hanya saja nilai

\footnotetext{
${ }^{37}$ Lihat A. Julianto, Pengantar Ringkas Antropologi (Jakarta:Pradnya Paramaita, 1981), 21-23.

38 Parsudi Suparlan, "Perubahan Sosial", Dalam Wijaya (ed.), Manusia Indonesia: Individu, Keluarga dan Masyarakat (Jakarta: Akademika Pressindo, 1986), 123.
} 
epistemologisnya yang diubah, seperti pisuke yang tadinya jumlahnya ditentukan menurut kebngsawanan pihak si istri, kini hanya sebagai penyenang (pengambil hati) orang tua si istri. Memulai dan menutup setiap prosesi adat dengan salam, basmalah, shalawat dan kalimah tayyibah lainnya. Melalukan perubahan makna epistemologis dari simbol adat, seperti dalam ajikrma, kewajiban si suami memberikan seperangkat untuk si calom istri, kepeng (sejumlah uang) sebagai simbol kewajiban memeberikan nafkah si istri dan anak keturunan, sebilah keris sebagai simbol kewajiban melindungi istri dan keturunan, kereng (kain selendang) sebagai simbol kewajiban memberikan mut'ah kepada si istri, dan sebidang tanah sebagai symbol kewajiban menyediakan tempat tinggal bagi keluarga (maskan). Ketiga, model rejeksi atau resistensi. Seperti penolakan masyarakat untuk tidak melakukan prosesi melaing, dan prosesi ajikrama, karena itu adalah bentuk adat. Dua model terakhir memnunjukkan bahwa masyarakat indonesia memiliki mekanisme tersendiri dalam menghadapi kehadiran budaya luar, termasuk yang terjadi di kalangan masyarakat Sasak Lombok, khususnya Kopang.

Dalam interaksi dua kebudayaan yang terjadi di Kopang, berlanjut dengan adanya upaya modifikasi antara kedua kebudayaan, model semacam ini dalam istilah Gus Dur (Abdurrahman Wahid) dikenal dengan teori Pribumisasi Islam, Pribumisasi Islam lahir dalam konteks perhatian Gus Dur untuk tidak menjadikan Islam sebagai alternatif terhadap persoalan kenegaraan dan kebangsaan. Pribumisasi Islam adalah upaya "mengokohkan kembali akar budaya dengan tetap menciptakan masyarakat yang taat beragama." 39

Teori pribumisasi merupakan proses timbal balik, yang produktif dan kreatif, yang melibatkan subjek-subjek aktif melakukan akomodasi, dialog, negosiasi, ataupun resistensi. Dengan kata lain, ia diletakkan dalam konteks kesejarahannya, relasi kuasa, dan hubungan antara kekuatan dominasi dan subordinasi. Pribumisasi merupakan arena kontestasi, di mana makna dipertarungkan dan tidak diletakkan dalam perspektif dominan semata. ${ }^{40}$

Penggunaan perspektif intraksi dalam melihat relasi Islam dan budaya lokal yang bermuara pada teori pribumisasi Islam yang dicetuskan oleh Abdurrahman

${ }^{39}$ Ahmad Basso, Plesetan Lokalitas: Politik Pribumisasi Islam (Jakarta: Desantara, 2002), 8.

40 Ibid., 7. 
Wahid. Dari hal tersbut, model modifikasi dalam upaya menginteraksikan dua kebudayaan yang berbeda dan berdampingan secara ramah, tanpa harus saling mendiskriminasikan atau saling dikotomi, sedangkan model rejeksi sebagai upaya pertahanan budaya lokal dalam menerima pengaruh budaya luar, dalam hal ini Islam, artinya tradisi lokal mempunyai daya tawar untuk bertahan sebagai sistem nilai yang harus dipegang oleh penganutnya, sehingga budaya lokal tidak terkikis habis, melainkan perubahan hanya terjadi pada hal tertentu saja, atau bahkan hanya pada epistemologisnya saja. Sehingga pertemuan atau interaksi antara dua kebudayaan yang terjdai di Kopang merupakan interaksi dua kekuatan yang berelaborasi dan berdampingan secara ramah.

Sebagaimana telah disebutkan sebelumnya, proses akulturasi Islam dengan tradisi lokal masyarakat Lombok dilakukan dengan cara dialog kebudayaan. Kebudayaan lokal yang bersumber dari keyakinan lokal tidak serta merta diubah begitu saja. Bahkan, tokoh spritual lokal seperti Tuan Guru Aris hingga saat ini masih bertahan. Kliang, pembayun (tokoh adat) bahkan masih memiliki ruang dalam ritual pernikahan bangsawan Sasak. Kliang, pembayun dan pengulu memiliki fungsi ritual masing-masing. Pengulu berfungsi sebagai puncak dari keseluruhan spritualisme Islam, sedangkan pembayun, kliang berfungsi dalam proses melangsungkan prosesi tradisi pernikahan bangsawan Sasak, yakni untuk menyelesaikan hal-hal yang berakaitan dengan tradisi yang harus dipenuhi oleh kedua mempelai dan keluarganya, dan pengulu berfungsi untuk menikahkan kedua mempelai dan memenuhi syarat ataupun unsurunsur yang berkaitan dengan agama Islam yang harus terpenuhi serta nasihat-nasihat berumah tangga. Hadirnya dua narasumber kebudayaan ini merupakan hasil dari proses dialog Islam dengan kebudayaan lokal. Para ahli agama yang direpresentasikan oleh Tuan Guru dan pengulu tidak dihadirkan untuk mereduksi simbol lokal seperti kliang, pembayun.

Dalam proses akulturasi Islam melalaui dialog jelas berbeda dengan dominasi. Proses dialog memungkinkan bagian dari produk kebudayaan lokal tetap bertahan. Praktik masyarakat Islam Lombok yang diduga berasal dari kebudayaan pra-Islam masih tetap dipraktekkan, seperti tradisi melaiang pengantin perempuan, nyelabar, sejati, gantiran, ajikrama, menserah, dalam prosesi pernikahan Sasak, berkata jorok untuk memancing keluar nyali (sejenis cacing) dari pensembuhyiannya di laut, dan lain 
sebagainya. Kesemua produk kebudayaan ini jelas bukan bagian dari inspirasi Islam, tetapi bersumber dari inspirasi lokal. Bertahannya tradisi lokal di tengah kedatangan nilai baru menunjukkan dua hal. Pertama, para Islamisator menganggap: produk kebudayaan tersebut dapat didialogkan dengan nilai Islam dengan mengubah pemaknaan simbolik ritual tersebut. Artinya, produk kebudayaan tersebut telah mengalami proses tranformasi di bagian nilai filosofisnya. Kedua, masyarakat lokal menggap kegiatan praktek kebudayaan tersebut tidak bisa dihilangkan, karena ia merupakan bagian dari proses ritual. Misalnya, berkata jorok dalam laut untuk memancing nyale keluar dari persembunyiannya dari dalam laut, adalah proses tradisi, kebutuhan dalam proses tradisi.

\section{Catatan Akhir}

1. Dalam hubungan manusia antar lain jenis kelaminnya, Islam mengatur dengan lembaga pernikahannya. Dalam pernikahan, selain mengandung dimensi ketakwaan kepada Allah SWT, juga sebagai menifestasi sunnah Nabi SAW. Pernikahan tidak hanya menyangkut dimensi religious saja, tetapi juga unsur sosial dan budaya sebagai lembaga legalitas hubungan dan keturunan yang sah.

Dalam memilih pasangan, Islam tidak menutup mata dari pertimbangan sosial dan fanawi, sepeti kecantikan, kekayaan, keturunan, pendidikan, intelegensi, peropesi dan lain-lain yang diharapkan memberikan dampak positif bagi keluarga dan anak baik secara sosial budaya maupun agama (kafa $>$ 'ah). Islam juga menganjurkan agar selektif dalam mencari jodoh, jangan yang mempunyai perangai buruk, jelek, berpenykit, kurang ekonomi, tidak cerdas dan lain-lain, karena hal tersebut bisa mempengaruhi keharomonisan keluarga dan keturunan yang akan dihasilkan, meski hal ini tidak menjadi faktor utama dalam pencapaian tujuan pernikahan; saki>nah mawaddah wa rahmah, akan tetapi tidak dipungkiri bahwa memunculnya konflik yang berujung perceraian sering berpangkal dari tidak terpenuhinya faktor tersebut. Pernikahan dalam Islam massif pengetahuan, keyakinan, sistem nilai dan tingkah laku, dan simbolisasi sakralitas yang harus dipegang.

2. Masyarakat suku Sasak adalah penduduk asli dan kelompok etnis mayoritas yang mendiami pulau Lombok. Dalam masyarakat Sasak, dikenal sistem stratafikasi sosial yang ditandai dengan gelar tertentu di awal nama mereka. Ada tiga tingakatan yang terdapat dalam sistem statafikasi sosial Sasak, yaitu; golongan 
bangsawan menak atas / perwangse yang berasal dari keturunan raja, yang bergar raden dan dinda. Golongan bangsawan menak menengah yang berasal dari perkawinan campuran antara laki-laki menak atas dengan perempuan jajar karang yang bergelar Gelar lalu dan lale atau baiq. Dan golongan jajar karang atau rakyat biasa dan tidak memiliki gelar khusus.

Dalam kehidupan sehari-hari, antara lapisan-lapisan tersebut terdapat perbedaan dalam sopan santun dan tutur bahasa. Dalam penggunaan bahasa, bahasa Sasak juga mengenal tingkatan bahasa, yaitu bahasa halus/utama, bahasa madya, dan bahasa biasa.

3. Sebelum Islam datang, Sasak sudah mengenal pernikahan. Oleh karena itu pernikahan yang ada mengandung dua dimensi, dimensi adat yang sudah mengakar dan dilakukan secara turun temurun, yang menjadi asli tradisi pernikahan setempat. Dan dimensi Islam yang menjadi nilai, pengetahuan dan kepercayaan baru yang membaur di masyarkat dan berakulturasi dengan budaya yang sudah ada, membentuk buaya baru.

Dalam adat tradisi pernikahan Sasak yang disebut merarik, ia dilakukan melalui tahapan-tahapan ketentuan adat yang meliputi: proses perkenalan dan pemilihan jodoh, dan lari bersama untuk merarik dan proses penyelaiannya serta aqad perkawinannya.

Pertama, tahap perkenalan dan pemilihan jodoh melalui lembaga adat yang disebut midang. Jika masing-masing pihak sudah merasa tertarik, maka terjadilah hubungan asmara yang disebut beberayean atau bekemelean (berpacaran). Kedua, melaiang dan proses penyelesaiannya.

Dengan terjadinya merarik, berbagai tindakan adat yang mengarah pada terjadinya perkawinan mulai dilakukan oleh kedua mempelai. Tindakan tersebut meliputi: sejati (pemberitahuan kepada pihak keluarga perempuan bahwa anaknya dilarikan untuk dinikahi), selabar (permintaan izian dari keluarga si laki kepada keluarga si perempuan untuk dinikahkan, disertai dengan pembahan adat, ajikraman, pisuke) dan ngawinang (aqad nikah).

Terakhir adalah upacara perkawinan yang meliputi sorong serah pembayunan dan nyongkolan. Sorong serah merupakan suatu seremoni perkawinan adat yang diadakan untuk memberikan dan menyerahkan aji krama serta benda-benda pelanggaran adat. 
Aji krama merupakan simbolisasi dari tingkat status sosial kedua mempelai, terutama mempelai perempuan serta anak keturunan yang dilahirkannya. setelah seremoni sorong serah dan pembayunan selesai, selanjutnya diakhiri dengan upacara nyongkolang.

4. Akulturasi Islam dan budaya lokal Sasak dimulai dari kedatangan para ulama penganjur Islam di Lombok yang ramah dengan tradisi lokal dan berperspektif Nusantara.

Proses pembentukan tradisi lokal pada masyarakat adat Sasak melalui cara reinterpretasi tradisi lokal dengan perspektif Islam, dan reformulasi tradisi Islam dengan prespektif lokal. Cara pertama mengalihkan tradisi lokal ke dalam lingkungna kognisi Islam tanpa mengubah model dan performancenya. Cara kedua memformulasi tradisi Islam dengan corak lokal. Kedua model inilah yang disebut pribumisasi Islam, suatu teori pertemuan budaya yang mengandaikan terjadinya saling mempelajari, saling mempengaruhi, dan saling membentuk. Kedua model interaksi ini menunjukkan bahwa antara Islam dan budaya lokal memiliki kekuatan yang relatif seimbang.

5. Para agen akulturasi dan tokoh adat setempat memposisikam diri menurut peran dan fungsi masing, meskipun tidak jarang meski meski bertemu dalam acara adat tertentu, Tuan Guru memerankan tugas dan funginya dalam mengatur perkawinan menurut hukum Islam, sedangkan tokoh adat memerankan tugas dan fungsinya dalam menyelesaikan persoalan-persoalam adat yang mesti di ikuti oleh kedua mempelai. Meskipaun mereka mempunyai peran masing-masing, akan tetapi tidak jarang bertemu dalam satu acara tertentu. Tuan Guru menjadi sentral agen akulturasi Islam dan budaya lokal.

Dalam interaksi Islam dan budaya lokal, terjadi beberapa pola akulturasi, yaitu: resistensi Islam terhadap tradisi minum miras dalam nyongkolan, mantera-mantera yang berisi kemusrikan. Selanjutnya pola integrasi atau modifikasi, pola ini mengindikasikan ramah tamah Islam terhadap budaya lokal dan ramah tamah lokal terhadap Islam dengan integrasikan Islam dalam budaya lokal, seperti terlihat dalam berbagai peristiwa atau phenomena pernikahan bangsawan Sasak Kopang Lombok. Baik secara performancenya maupun kognisinya, seperti pemaknaan aji karma, pisuke, melaiang, dan simbolisasi aji karma dan lain-lainnya. 


\section{Daftar Rujukan}

A.G., Muhamin, Islam dalam Bingkai Budaya Lokal: Potret dari Budaya Cirebon, Jakarta: Logos, 2001.

Bartholomew, Jhon Ryan, Alif Lam Mim: Kearifan Masyarakat Sasak, Yogyakarta: Tiara Wacana Yogya, 2001.

Basso, Ahmad, Plesetan Lokalitas: Politik Pribumisasi Islam, Jakarta: Desantara, 2002.

Budiwanti, Erni, Islam Sasak: Wetu Telu Versus Wetu Lima, Yogyakarta: LKIS, 2000.

Departemen Pedndidikan dan Kebudayaan NTB, Adat Istiadat Daerah Nusa Tenggara Barat, Mataram: Proyek Penelitian dan Pencatatan Kebudayaan Daerah, 19771978.

Goode, William J., Sosiologi Keluarga, Terj. Lalahanoum Hasyim, cet. II, Jakarta: Bina Aksara, 1985.

Hadi, Sutrisno, metodologi research, jlid II, Yogyakarta: Yayasan Penerbitan Fakultas UGM, 1986.

Hamidjojo, R. Soetoyo Prawiro, Pluralisme Dalam Perundang-Undangan Perkawinan di Indonesia, Surabaya: Airlangga University Press, 1988.

Haviland, William A., Antropologi, Jakarta: Erlangga, edisi ke empat, 1988.

Hidayat, Akulturasi Islam dan Budaya Melayu, Jakarta: Badan Litbang dan Diklat Kementrian Agama, 2009.

Julianto, A., Pengantar Ringkas Antropologi, Jakarta: Pradnya Paramita, cetakan kedua, 1981.

Lukito, Ratno, Pergumulan antara Hukum Islam dan Adat di Indonesia, Jakarta: INIS, 1998.

Soekanto, Meninjau Hukum Adat Indonesia Suatu Pengantar Untuk Mempelajari Hukum Adat, Jakarta: CV. Rajawali, 1981.

Sudirman, Gumi Sasak Dalam Sejarah, Selong: Yayasan Budaya Sasak Lestari, 2007.

Syaltout, Mahmoud, Al-Islam 'Aqidah wa Syari'ah di Indosiakan oleh H. Bustami A. Hamdani Alidengan judul Islam sebagai Aqidah dan Syariah, Jakarta: Bulan Bintang, 1975.

Yasin, M.Nur, Hukum Perkawinan Islan Sasak, Malang: UIN-Malang Press, 2008.

'Abbs Ahmad bin 'Umar al-dayrabi al-Syafi'I, Abu, Abka $>m$ al-Zawa $>$ ' ala $>$ alMaza $>$ bib al-Arba'ah, Beirut: Da>r al-Kutub al-imiyyah 1986. 
Abu Zahrah, Muhammad, al-Ahwa >l al-Syakbsiyyah, cet-III (ttp : da>ral-Fikr al-'Arabi> $1377 / 1957$.

Assagaf, Djamaluddin, Kafa >'ah, hlm. 11. Dan Hasyim Assagaf, Derita Putri-Putri Nabi: Studi Historis Kafa >’ab Syrifah, Bandung: PT. Remaja Rosdakarya, 2000.

http://kodepos.nomor.net/_kodepos.php?_i=desa kodepos\&sby=000000\&daerah= Kecamatan-Kab.-Lombok\%20Tengah\&jobs=Kopang 